29. Вавринчук М.П. Етнополітичная безпека в системі національної безпеки України на етапі сучасного державотворення. Київ : Правова єдність, 2009. 288 с.

30. Хачатурян Х.В. Переорієнтація державного управління на потреби громадян: нова європейська модель та Україна. Вісник Київського міжнародного університету. Серія: Міжнародні відносини. 2009. № 8. URL: http://www.kymu.edu.ua/vmv/v/08/khachaturian.htm.

УДК 342.9

DOI https://doi.org/10.32844/2618-1258.2019.5-1.26

ДЕГТЯРЬОВА С.В.

\title{
ПОНЯТТЯ ТА СУТНІСТЬ ПРАВОВОГО СТАТУСУ СУБ'ЄКТІВ ДЕРЖАВНОГО РЕГУЛЮВАННЯ В АГРОПРОМИСЛОВІЙ СФЕРІ
}

У статті на основі аналізу наукових поглядів учених надано авторське визначення поняття правового статусу суб'єктів державного регулювання в агропромисловій сфері. Обгрунтовано, що правовий статус суб'єктів державного регулювання в агропромисловій сфері є складною збірною категорією, яка включає у себе цілу низку елементів, що пов'язані між собою, доповнюють один одного та у сукупності відображають, яке місце посідає той чи інший суб'єкт у відповідній системі. 3'ясовано, що соціальний статус відображає положення особи в суспільстві, своєю чергою, правовий статус його конкретизує та є об' єктивним показником положення суб'єкта у конкретних правовідносинах. В юридичній літературі сформовано чималу кількість підходів до визначення поняття «правовий статус». Наголошено на важливості правового статусу, а саме політичні та юридичні гарантії забезпечення правового статусу суб'єктів державного регулювання агропромислової сфери. Зокрема, політичні гарантії слід розуміти як сукупність визначених законом умов, засобів, інструментів та способів, які спрямовуються на забезпечення ефективної роботи уповноважених суб'єктів у досліджуваній сфері. Уважаємо, що політичні гарантії надають їхній діяльності більшої цілеспрямованості, визначають конкретний вектор для подальшої роботи органів державної влади у цій сфері. Що ж стосується юридичних гарантій, то їх найбільш важливе призначення полягає у тому, що держава повинна створити необхідне правове поле, надати їм усі необхідні права, обов'язки та повноваження для того, щоб окреслені вище суб'єкти могли якісно й ефективно вирішувати завдання, які стоять перед ними, та виконувати свої функції. Визначено, що під правовим статусом суб'єктів державного регулювання в агропромисловій сфері необхідно розуміти сукупність суб'єктивних прав, юридичних обов'язків тощо, які закріплені нормами чинного законодавства України та визначають положення уповноваженого суб'єкта у відповідній системі. Відзначено, що правовий статус не лише охоплює багато аспектів, які характеризують відповідний суб'єкт, він ще й складається з великої кількості елементів, аналіз яких, своєю чергою, надасть більш об'єктивну картину щодо сутності, змісту та призначення окреслених у роботі суб'єктів.

Ключові слова: статус, соиіальний статус, правовий статус, суб'єкт, державне регулювання, агропромислова сфера.

In the article, based on the analysis of scientific views of scientists, the author defines the concept of legal status of the subjects of state regulation in the agro-industrial sphere. It is substantiated that the legal status of the subjects of state regulation in the agro-industrial sphere is a complex assembly category that includes a number of elements that are

(C) ДЕГТЯРЬОВА С.В. - кандидат юридичних наук, докторант (Харківський національний університет внутрішніх справ) 
interconnected, complement each other, and in the aggregate reflect which place is occupied by a particular subject in appropriate system. It is found that social status reflects the position of the person in society, in turn, the legal status specifies it and is an objective indicator of the position of the subject in specific relationships. In the legal literature, a number of approaches to defining the concept of "legal status" have been formed. It is emphasized that the importance of legal status, namely the political and legal guarantees of ensuring the legal status of the subjects of state regulation of the agro-industrial sphere. In particular, political safeguards should be understood as the set of statutory terms, conditions, tools and methods that aim to ensure the effective functioning of authorized entities in the research field. We believe that the political guarantees give them more purposeful activity, determine a specific vector for the further work of public authorities in this area. As for legal safeguards, their most important purpose is that the state must create the necessary legal field, give them all the necessary rights, duties and powers to enable the above entities to fulfill their tasks efficiently and effectively, who stand before them and perform their functions. It is determined that under the legal status of the subjects of state regulation in the agro-industrial sphere it is necessary to understand a set of subjective rights, legal obligations, etc., which are enshrined in the norms of the current legislation of Ukraine and determine the provisions of the authorized entity in the relevant system. It is noted that the legal status not only covers many aspects that characterize the subject, it also consists of a large number of elements, the analysis of which in turn will give a more objective picture of the nature, content and purpose of the entities outlined in the work.

Key words: status, social status, legal status, subject, state regulation, agro-industrial sphere.

Вступ. В умовах економічної, політичної, соціальної та економічної кризи в Україні велике значення має пошук джерел фінансування різних галузей життя нашої держави. Одним із таких джерел, беззаперечно, $є$ агропромислова сфера, від ефективності управління якою напряму залежить її функціонування. Своєю чергою, державне регулювання даної галузі неможливе без якісної роботи відповідних суб'єктів. Система суб'єктів державного регулювання в агропромисловій сфері представлена чималою кількістю уповноважених органів, кожен з яких виконує власну специфічну роль у досліджуваній галузі, що перш за все зумовлено їхнім особливим правовим статусом, дослідження якого має велике теоретичне та практичне значення, адже саме правовий статус $є$ тією категорією, яка найбільш змістовно та якісно відображає положення суб'єкта у відповідній системі.

Окремі проблемні питання діяльності суб'єктів державного регулювання в агропромисловій сфері у своїх наукових дослідженнях розглядали: М.Ю. Покальчук, І.С. Окунєв, О.О. Тертичний, Т.М. Куценко, Л.Г. Макарова, М.О. Кальніцька, О.Р. Заяць, Г.В. Осипова, О.Ю. Прокопенко, А.П. Мукшименко, Н.М. Оніщенко, О.В. Петришин, С.П. Погребняк, В.С. Смородинський та багато інших. Однак, незважаючи на чималу кількість наукових розробок, питання сутності та змісту правового статусу суб'єктів державного регулювання в агропромисловій сфері фактично залишилося поза увагою науковців.

Постановка завдання. Метою статті $\epsilon$ визначення поняття та сутності правового статусу суб'єктів державного регулювання в агропромисловій сфері.

Результати дослідження. В юридичній літературі коли йдеться про «статус» фізичної або юридичної особи, то перш за все мається на увазі «правовий статус». Однак слід указати, що, оскільки зміст правового статусу визначається соціальним статусом (та $є$ його складовим елементом), то велике значення має дослідження змісту останнього. Слід також відзначити, що соціальний статус і його елемент - правовий статус зумовлені історичними особливостями, типом держави, в якій живе особа, політичним режимом та рівнем розвитку держави, громадянського суспільства, правової системи. «Юридичний статус людини і громадянина як у цілому, так і зокрема зумовлюється особливостями соціального статусу, який існує в певний період розвитку суспільства і держави» [1, с. 28]. Вказане доведено історичними передумовами, оскільки навіть «за часів Середньовіччя окремий індивід не уявляв себе поза економічною, соціальною, соціокультурною, релігійною сферами, за межами свого чітко фіксованого статусу і рольових функцій в означених сферах, які, своєю чергою, становили невід'ємне ціле 3 державою, політичною сис- 
темою. Найважливіші інституції людської діяльності, такі як власність, родина, організація праці у формі феодального володіння землею, касти, корпорації, набували статусу елементів державного життя. 3 їх допомогою віднесення індивіда до офіційної організації встановлювалося через систему соціальних, а згодом політичних статусів» [2, с. 27].

Поняття «соціальний статус» уперше почало використовуватися у Стародавньому Римі (власне термін «статус» походить із латинської мови й означає «становище»), і його трактування було близьким до сучасного, тобто це поняття визначало положення людини в суспільстві. Соціальний статус, продовжують В.В. Вербець, О.А. Субот та Т.А. Христюк, - це положення соціального суб'єкта в суспільстві, що передбачає для нього певні специфічні права й обов'язки, правила поведінки. Таким чином, соціальний статус визначає становище індивіда або соціальної групи стосовно інших індивідів і груп, яке визначається за соціально значущими для даної соціальної системи критеріями (економічними, політичними, соціально-правовими, професійно-кваліфікаційними тощо) [3]. Протягом багатьох років у науковій літературі сформувалася чимала кількість наукових підходів до розуміння соціального статусу.

Так, у філософських колах відзначається, що соціальний статус розкриває співвідносне положення (позицію) індивіда або групи в соціальній системі, яке визначається за низкою ознак, специфічних для даної системи (економічних, професіональних, етнічних та ін.). Особи, що володіють одним і тим же статусом, виявляють низку схожих особистісних рис, що позначаються як «соціальний тип» особистості. Кожен статус може порівнюватися з іншим із тією чи іншою ознакою, співвідносними 3 панівною системою цінностей, набуваючи, таким чином, певний соціальний престиж [4, с. 626]. Д.М. Ластович доводить, що соціальний статус - це комплексна категорія, яка характеризує місце суб'єкта в певній соціальній системі через визначення його соціальної ролі з відповідними їй функціями, правами й обов'язками. При цьому вчений підкреслює, що окремим специфічним різновидом соціального статусу є правовий статус, який набувається суб'єктами внаслідок регулятивного впливу на них норм права [5, с. 73].

Є.О. Ануфрієв під соціальним статусом розуміє поняття, що визначає місце особистості в системі суспільних відносин, іiї права і свободи, зафіксовані в Конституції (правовий статус), можливості для всебічного розвитку і застосування своїх здібностей, основні функції особистості як суб'єкта суспільних відносин, розкриває ії діяльність в основних сферах життя i, нарешті, дає оцінку їі діяльності з боку суспільства в кількісних і якісних показниках (заробітна плата, премії, нагороди, звання, привілеї), а також самооцінку, що може збігатися або не збігатися 3 оцінкою суспільства [6, с. 178]. Цікавою є точка зору С.О. Рамазанова, який, аналізуючи існуючі теорії природи соціального статусу, виділяє декілька основних підходів до розуміння поняття соціального статусу. По-перше, соціальний статус може розумітися як позитивна чи негативна репутація, престиж, авторитет особистості в рамках системи соціальної стратифікації [7, с. 294; 8]. По-друге, як сукупність прав та обов'язків індивіда чи соціальної групи, що пов'язана 3 виконанням ними певної соціальної ролі. По-третє, поняття «соціальний статус» може бути розглянуте як положення індивіда в системі міжособистісних відносин, зумовлене його психологічним впливом на членів групи. По-четверте, як співвідносну соціальну позицію індивіда чи соціальної групи, що визначена соціальними показниками (економічне положення, професія, кваліфікація, освіта тощо), природними (стать, вік), а також престижем і місцем у структурі влади [9, с. 343].

Таким чином, соціальний статус відображає положення особи в суспільстві; своєю чергою, правовий статус його конкретизує та є об'єктивним показником положення суб'єкта у конкретних правовідносинах. В юридичній літературі сформовано чималу кількість підходів до визначення поняття «правовий статус». Зокрема, В.М. Корельський та В.Д. Перевалов визначають правовий статус як багатоаспектну категорію, що, по-перше, має загальний, універсальний характер, включає статуси різних суб'єктів правовідносин: держави, суспільства, особи тощо; по-друге, відображає індивідуальні особливості суб'єктів і реальне положення їх у системі багатоманітних суспільних відносин; по-третє, правовий статус не може бути реалізований без обов'язків, що кореспондуються правам, без юридичної відповідальності в необхідних випадках, без правових гарантій; по-четверте, категорія «правовий статус» визначає права й обов'язки суб'єктів у системному вигляді, що дає змогу здійснити порівняльний аналіз статусів різних суб'єктів для відкриття нових шляхів для їх удосконалення [10, с. 549]. М.I. Матузов та А.В. Малько визначають правовий статус як складну категорію, що відображає весь комплекс зв'язків людини із суспільством, державою, колективом тощо, і структурними елементами якого є правові норми, які встановлюють даний статус, правосуб'єктність, права та обов'язки, законні інтереси, юридичну відповідальність, правові принципи, правовідносини [11, с. 231]. 
Досить розгорнуто зміст даного поняття розкриває О.Ф. Скакун. Учена вказує, що правовий статус (від лат. status - положення, стан) - юридично закріплене становище людини в суспільстві, відповідно до якого фізична особа як суб'єкт права вступає у правовідносини, координує свою діяльність і поведінку в суспільстві. На переконання вченої, ознаками правового статусу є такі: 1) залежить від сутності соціального ладу, в умовах якого він складається і функціонує; зазнає впливу безлічі чинників, основними з яких $є$ праця і власність як основа формування громадянського суспільства; 2) виступає як юридична міра соціальної свободи суб'єкта права; 3) установлюється спеціально уповноваженими органами держави, його зміст змінюється з волі законодавця, а не окремих суб'єктів права, на яких він поширюється; 4) відображається у правових нормах і принципах, формально закріплених у приписах нормативно-правових актів, нормативно-правових договорів та в інших джерелах (формах) права; 5) має визначену структуру, ядро якої становлять суб'єктивні права, законні інтереси, обов'язки, що є однаковими для всіх його носіїв одного виду; 6) встановлює межі, за які не повинні виходити діяльність і поведінка людини в суспільстві [12]. О.Ф. Скакун також доводить, що правовий статус людини грунтується на сучасному вченні про свободу, в основі якого лежать ціннісні ідеї: 1) усі люди вільні від народження, і ніхто не має права відчужувати їхні природні права. Забезпечення реалізації, охорони і захисту цих прав - головний обов'язок держави; 2) свобода особи полягає у можливості робити все, що не завдає шкоди іншій особі; 3) межі свободи можуть бути визначені законом, який відповідає праву (природженим правам людини), а право є мірою свободи, достатньою для повного самовираження людини; 4) обмеження прав можливе лише з метою сприяння досягненню загального добробуту в демократичному суспільстві та перешкоджання будь-яким спробам особи використовувати надану їй свободу на шкоду суспільству, державі, співгромадянам. Суспільство, забезпечуючи свободу особи, не може допускати анархії, беззаконня, обмеження прав і законних інтересів інших громадян, свавілля держави. Ці ідеї $є$ витоками й осердям принципу верховенства права [12].

Таким чином, виходячи з наведеного вище, можна підсумувати, що під правовим статусом суб'єктів державного регулювання в агропромисловій сфері необхідно розуміти сукупність суб'єктивних прав, юридичних обов'язків тощо, які закріплено нормами чинного законодавства України та визначають положення уповноваженого суб'єкта у відповідній системі. Варто відзначити, що правовий статус не лише охоплює багато аспектів які характеризують відповідний суб'єкт, він ще й складається з великої кількості елементів, аналіз яких, своєю чергою, надасть більш об'єктивну картину щодо сутності, змісту та призначення окреслених у роботі суб'єктів. Тож до таких елементів, на нашу думку, слід віднести:

1) суб'єктивні права. Як елемент правового статусу суб'єктів державного регулювання агропромислової сфери суб'єктивні права являють собою міру можливої поведінки даних суб'єктів із метою вирішення покладених на них завдань та виконання відповідних функцій у досліджуваній сфері суспільних відносин. Варто відзначити, що від повноти та якості користування відповідними органами своїми правами напряму залежить регулювання агропромислової сфери в Україні. Тож важливе завдання держави - наділити уповноважені органи таким колом прав, яких, по-перше, буде достатньо для виконання їх обов'язків у цій сфері, а по-друге, такі права законодавець повинен також певним чином обмежувати щоб уникнути зловживання ними. Суб'єктивні права тісно пов'язані з таким елементом правового статусу, як юридичні обов'язки;

2) юридичний обов'язок на відміну від суб'єктивних прав указує на те, які дії повинні вчинити суб'єкти державного регулювання в агропромисловій сфері $з$ метою здійснення ефективного та результативного регулювання нею;

3) повноваження, які є збірною категорією, що включає в себе сукупність прав та обов'язків уповноважених суб'єктів. Повноваження визначають межі будь-якої діяльності, рамки відповідальності, звітності, підконтрольності, формують єдину систему будь-якого органу [13, с. 215];

4) правосуб'єктність. Як зазначає Р.О. Халфіна, правосуб'єктність - це елемент правового статусу особи і можливість виступати як суб'єкт прав і обов'язків у різних галузях суспільних відносин [14]. Погоджуючись із точкою зору В.М. Корельского та В.Д. Перевалова, відзначимо, що правосуб' єктність - це передбачена нормами права здатність (можливість) бути учасником правовідносин. Вона являє собою складну юридичну властивість, що складається 3 двох елементів - правоздатності та дієздатності. Правоздатність - це передбачена нормами права здатність (можливість) особи мати суб'єктивні права та юридичні обов'язки. Дієздатність - передбачена нормами права здатність та юридична можливість особи своїми діями набувати права й обов'язки, здійснювати та виконувати їх [15, с. 343-344]. Отже, правосуб'єктність - це не просто визначені законом юридичні права та обов'язки суб'єктів державного регулювання, вона передбачає можливість їх мати і реалізовувати належним чином; 
5) відповідальність. Як елемент правового статусу суб’єктів державного регулювання агропромислової сфери відповідальність має декілька важливих аспектів: по-перше, вона є своєрідним стимулюючим чинником для органів державної влади та їхніх посадових осіб якісно та ефективно виконувати покладені на них обов'язки; по-друге, юридична відповідальність передбачає застосування заходів негативного характеру до уповноважених у разі невиконання (або неналежного виконання) ними своїх обов'язків. Даний аспект, своєю чергою, є важливим превентивним заходом для вчинення проступків у цій сфері;

6) гарантії правового статусу. Що стосується безпосередньо окресленої проблематики, то найбільш велике значення, на нашу думку, мають політичні та юридичні гарантії забезпечення правового статусу суб'єктів державного регулювання агропромислової сфери. Зокрема, політичні гарантії слід розуміти як сукупність визначених законом умов, засобів, інструментів та способів, які спрямовуються на забезпечення ефективної роботи уповноважених суб'єктів у досліджуваній сфері. Уважаємо, що політичні гарантії надають їхній діяльності більшої цілеспрямованості, визначають конкретний вектор для подальшої роботи органів державної влади у цій сфері. Що ж стосується юридичних гарантій, то їх найбільш важливе призначення полягає у тому, що держава повинна створити необхідне правове поле, надати їм усі необхідні права, обов'язки та повноваження для того, щоб окреслені вище суб'єкти могли якісно й ефективно вирішувати завдання, які стоять перед ними, та виконувати свої функції.

Висновки. Завершуючи представлене наукове дослідження, необхідно підсумувати, що правовий статус суб'єктів державного регулювання в агропромисловій сфері є складною збірною категорією, яка включає у себе цілу низку елементів, які пов'язані між собою та доповнюють один одного. У своїй сукупності дані елементи відображають, яке місце посідає той чи інший суб'єкт у відповідній системі. А отже, дослідження правового статусу суб'єктів державного регулювання в агропромисловій сфері має велике теоретичне та практичне значення.

\section{Список використаних джерел:}

1. Воєводин Л.Д. Юридический статус личности в России : учебное пособие. Москва : ИНФРА • М-НОРМА, 1997. 304 с. C. $26-29$.

2. Тарнавська А.Н. До питання про юридичний статус особи. Адвокат. 2009. № 3(102).

3. Вербець В.В., Субот О.А., Христюк Т.А. Соціологія : навчальний посібник. Київ : КОНДОР, 2009. 550 с.

4. Философский энциклопедический словарь / редкол. : С.С. Аверинцев и др. ; 2-е изд. Москва : Сов. энциклопедия, 1989. 815 с.

5. Ластович Д.М. Поняття адміністративно-правового статусу поліції як суб'єкта надання поліцейських послуг. Наше право. 2015. № 6. С. 71-75.

6. Ануфриев Е.А. Социальный статус и активность личности (Личность как объект и субъект общественных отношений). Москва : Моск. ун-т, 1984. 288 с.

7. Джери Д. Большой толковый социологический словар : в 2-х т. / пер. с англ. Н.Н. Марчук. Москва : Вече, АСТ, 1999. Т. 2. 528 с.

8. Ромазанов О.С. Структурні складові соціального статусу публічного службовця. Теорія та практика державного управління. 2014. Вип. 1. С. 259-266.

9. Социологический энциклопедический словарь. На русском, английском, немецком, французском и чешском языках / под ред. Г.В. Осипова. Москва : НОРМА, 2000. 488 с.

10. Корельський В.М., Перевалова В.Д. Теория государства и права : учебник для вузов Москва : НОРМА-ИНФРА, 2002. 616 с.

11. Теория государства и права : курс лекций / под ред. Н.И. Матузова и А.В. Малько. Москва : Юристъ, 1997. 768 с.

12. Скакун О.Ф. Теорія права і держави : підручник ; 3-є вид. Київ : Алерта; ЦУП, 2011. $524 \mathrm{c}$.

13. Ковтун І.Б. Поняття і сутність повноважень органів місцевого самоврядування на регіональному рівні. Держава та регіони. Серія «Державне управління». 2011. Вип. 1. С. 211-217. 1974. $351 \mathrm{c}$.

14. Халфина Р.О. Общее учение о правоотношении. Москва : Юридическая литература,

15. Теория государства и права / под ред. В.М. Корельского и В.Д. Перевалова. Москва : НОРМА-ИНФРА, 1998. 570 с. 